\title{
PENGGUNAAN UTANG PADA SAAT FASE PERTUMBUHAN: "KEPUTUSAN REAKTIF ATAU KEPUTUSAN RASIONAL
}

\author{
Bayu Sindhu Raharja \\ Muji Mranani \\ Universitas Muhammadiyah Magelang \\ bayusindhu@gmail.com
}

\begin{abstract}
The focus of this study is to test the effect of the company's growth and the company's performance. This research also tests whether the poor long-term performance of high growth company caused by the manager overreaction behavior in using debt for financing decisions. Debt policy decisions serve as a form of proxy decision-reactive managers in deciding the funding policy. The results of this study stated that the high growth companies have poor performance in the future. However, the poor performance in the future was not caused by reactive decision- making managers in using debt for financing their business. This study shows the opposite, the policy of the use of debt actually positively impact the company's performance in the future. Thus, the use of debt as a source of funding when the company is in a growth phase rational decisions.
\end{abstract}

Keywords: Firm Growth, Financing Decision, Debt to Equity Ratio, Firm Performance

\section{PENDAHULUAN}

Berdasarkan data dari Bank Indonesia tahun 2014 menunjukkan bahwa penggunaan utang menunjukkan tren peningkatan. Hal ini dapat dilihat dari meningkatnya jumlah emiten obligasi pada setiap tahunnya. Tahun 2014, peningkatan jumlah emiten berada dikisaran angka 5\% dari tahun sebelumnya. Begitu juga dengan nilai emisi obligasi, secara rerata terjadi peningkatan sebesar $18 \%$ pada tahun yang sama. Dua hal tersebut menunjukkan bahwa penggunaan utang sebagai sumber pendanaan secara general mengalami peningkatan beberapa tahun terakhir ini.

Ramezani et.al (2002) dalam artikel penelitiannya menyatakan bahwa ada beberapa perusahaan yang mengalami kebangkrutan justru ketika perusahaan tersebut telah mengalami pertumbuhan, ini disebabkan karena perusahaan tidak dapat mengontrol pertumbuhan perusahaan. Lehman Brothers, perusahaan yang bergerak dibidang keuangan asal Amerika Serikat dengan total asset yang dimiliki sebesar US \$ 640 milliar dan usia perusahaan adalah 158 tahun. Lehman Brothers merupakan salah satu pemain utama perusahaan bidang keuangan di Amerika Serikat. Hampir sulit membayangkan bahwa perusahaan tersebut akan terjerembab dalam kebangkrutan. Tapi, faktanya tahun 2002 perusahaan tersebut akhirnya mengalami kebangkrutan.

Maduro (2007: 67) mencontohkan Thailand pada tahun 1998 mengalami krisis keuangan yang sangat hebat setelah Negara tersebut mengalami pertumbuhan yang luar biasa pada periode sebelumnya. Dengan kata lain, 
pertumbuhan yang dialami perusahaan maupun Negara tersebut bisa dikategorikan sebagai pertumbuhan yang tidak berkualitas. Tetapi disisi yang lain, pertumbuhan perusahaan merupakan salah satu prasyarat, atau bahkan dapat menjamin agar perusahaan dapat terus berkembang. Maka dari itu, kemudian muncul pertanyaan, "Apa sebenarnya yang menjadi sumber masalah?”.

Ramezani et.al (2002), menyatakan bahwa pertumbuhan perusahaan harus menciptakan nilai, dalam konteks ini adalah nilai bagi para pemegang saham. Dengan seperti itu maka pertumbuhan perusahaan dapat dikatakan pertumbuhan yang berkualitas. Gombola dan Marciukaityte (2007) dalam riset yang dilakukannya, menyatakan bahwa perilaku reaktif manajer dalam pengambilan keputusan pendanaan merupakan sumber utama dari buruknya kualitas pertumbuhan perusahaan. Yang dalam konteks penelitiannya, ditunjukkan dengan penurunan pergerakan harga saham setelah keputusan pendanaan itu diambil. Perilaku reaktif tersebut dipicu oleh kondisi perusahaan yang sedang mengalami pertumbuhan. Manajer menaruh keyakinan berlebih sehingga memicu perilaku reaktif terhadap pemilihan sumber pendanaan (Gombola dan Marciukaityte, 2007; Wu dan Yeung, 2012).

Dalam perspektif yang berbeda, penggunaan utang sebagai sumber pendanaan dalam ranah keuangan dipandang sebagai suatu yang sebenarnya sangat rasional. Ini dijelaskan oleh pecking order theory (Myer, 1984; Myer, dan Majluf, 1984) dan teori keagenan (Jensen, dan Meckling, 1976). Dalam perspektif kedua teori tersebut, penggunaan utang sebagai sumber pendanaan memiliki biaya yang murah dibanding dengan skema pendanaan yang lain (Myer, 1984; Myer dan Majluf, 1984) dan dengan dapat meminimalisir konflik antara manajemen dan pemilik modal dengan peningkatan mekanisme kontrol (Jensen, dan Meckling, 1976; Anderson et.al, 2003). Jadi ada 2 (dua) perspektif teori yang berbeda dalam memandang penggunaan utang oleh perusahaan. Penelitian ini akan mengkonfirmasi perbedaan tersebut dengan cara menguji apakah benar seorang manajer berperilaku reaktif ketika memutuskan utang sebagai sumber kebijakan pembiayaan.

\section{REVIEW LITERATUR DAN HIPOTESIS}

Gombola, dan Marciukaityte (2007) dalam penelitiannya menyatakan bahwa seorang manajer akan berperilaku reaktif ketika memutuskan kebijakan pendanaan, ketika kinerja perusahaan pada masa lampau bagus. Kinerja (kondisi) bagus tersebut misalnya perusahaan pada periode sebelumnya memiliki pertumbuhan positif. Dengan kata lain manajer menaruh perhatian lebih pada informasi masa lalu sebagai rujukan utama dalam pengambilan keputusan. Teori keprilakuan dalam ranah keuangan ini berakar pada teori psikologi yang menyebutkan bahwa individu akan cenderung mengalami bias dalam penaksiran jika menggunakan informasi masa lalu (Weinstein, 1980). Apabila kondisi pada masa lampau bagus, hal ini akan menjadikan bias pengambilan keputusan semakin parah (Van Der Steen, 2004). Heaton (2002) dalam risetnya juga menyatakan demikian, bahwa seorang manajer akan cenderung berperilaku reaktif ketika mengambil keputusan ketika kinerja pada periode lampau menunjukkan hasil yang bagus.

Pecking order theory menyatakan bahwa utang merupakan opsi yang dipilih oleh manajer dibandingkan dengan saham dikarenakan memiliki biaya yang lebih murah dan relative lebih mudah untuk didapat (Myer, 1984; Myer, dan Majluf, 1984). Senada dengan pecking order theory, agency theory (Jensen, dan Meckling, 1976) pun menyatakan demikian. Anderson et.al (2003) dalam risetnya menyatakan bahwa penggunaan utang dapat meningkatkan mekanisme kontrol terhadap manajer dalam perusahaan, dengan meningkatnya mekanisme 
control tersebut maka konflik keagenan dapat diminimalisir. Maka dari itu, ketika perusahaan sedang tumbuh dan perlu biaya atas pertumbuhan tersebut, manajer perusahaan akan memilih sumber pembiayaannya dengan menggunakan utang karena proses mendapatkannya relatif lebih mudah dibanding ketika perusahaan menggunakan penerbitan saham.

$\mathrm{H}_{1}$ : Pertumbuhan perusahaan berpengaruh positif terhadap penggunaan utang

Akan tetapi, trade-off theory menyatakan bahwa semakin besar utang yang digunakan, maka semakin besar juga risiko yang akan ditanggung perusahaan. Risiko pembayaran bunga utang yang semakin besar, kemungkinan besar akan menyulitkan perusahaan dari sisi keuangan(Kraus and Litzenberger 1973;Scott 1977; Kim 1978). Jadi, dari perspektif trade-off theory penggunaan utang harus diperhatikan dengan melihat proporsi utang dengan ekuitas perusahaan, apabila penggunaan lebih besar daripada penggunaan ekuitas, ini berarti lampu kuning bagi perusahaan. Maka dari itu beberapa penelitian terdahulu menyatakan bahwa kebijakan penggunaan utang sebagai sumber pendanaan akan berdampak negatif terhadap kinerja perusahaan (Taggart, 1986; Kim et.al 2007; Su ,2004; Campello,2006, Heaton, 2007; Billet et.al, 2007; Marciukaityte, dan Szewczyk, 2011; Wu, dan Yeung,2012). Hal ini yang kemudian menjadi dasar Gombola, dan Marciutkaityte (2007) menyatakan bahwa penurunan kinerja disebabkan karena perilaku reaktif manajer dalam pengambilan kebijakan pendanaan. Penelitian ini akan menguji temuan tersebut dengan menggunakan mengintridusir variabel mediasi, maksudnya seandainya benar perilaku reaktif itu ada maka kebijakan pendanaan dengan utang akan memediasi hubungan antara pertumbuhan perusahaan dengan kinerja perusahaan.

$\mathrm{H}_{2}$ : Penggunaan utang perusahaan berpengaruh negatif terhadap kinerja perusahaan
$\mathrm{H}_{3}$ : Penggunaan utang memediasi hubungan antara pertumbuhan perusahaan dengan kinerja perusahaan

Adapun kerangka pemikiran dalam penelitian ini adalah sebagai berikut:

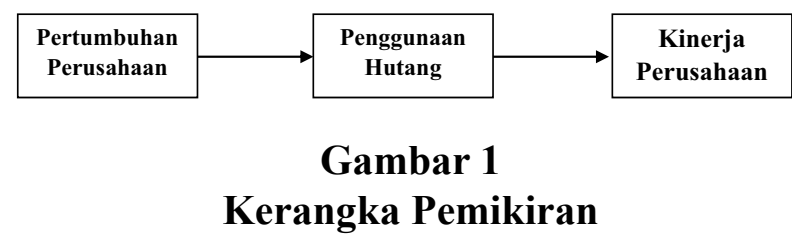

\section{METODE PENELITIAN}

Sampel yang digunakan dalam penelitian ini adalah perusahaan sector manufaktur yang terdaftar di Bursa Efek Indonesia dari tahun 1999 sampai dengan tahun 2010. Total perusahaan dari tahun tersebut sebenyak 1.922 perusahaan. Dari 1.922 perusahaan tersebut, pada masing-masing tahun akan dikelompokkan berdasar tingkat pertumbuhannya. Pertumbuhan perusahaan diukur dengan menggunakan tingkat pertumbuhan penjualan.

\section{Pertumbuhan Perusahaan: (Penjualan - $_{t}$ Penjualan $_{t-1}$ )/Penjualan t-1 $_{1}$}

Setiap tahunnya akan dikelompokkan menjadi 4 (empat) kategori yaitu Q1, Q2, Q3, dan Q4. Q1 adalah perusahaan - perusahaan dengan tingkat pertumbuhan paling tinggi. Q2 adalah perusahaan dengan tingkat pertumbuhan dibawah Q1, dan begitu seterusnya. Perusahaan pada kategori Q1 kemudian akan diambil kemudian dianalisa penggunaan utang dan kinerjanya. Penggunaan utang diukur dengan menggunakan rasio Debt to Equity Ratio (DER).

\section{DER = Total Debt/Total Equity}

Sedangkan kinerja akan dihitung kinerja saham tiga tahun setelah periode pengamatan, kemudian dibandingkan kinerjanya dengan kinerja pasar saham secara keseluruhan. Adapun alat analisa yang digunakan adalah model regresi 
berganda. Untuk menguji efek mediasi, dalam penelitian ini pengujian berdasarkan prosedur dari Baron, dan Kenny (1986). Adapun prosedurnya adalah sebagai berikut :

1) Menguji hubungan antara pertumbuhan perusahaan dengan kinerja perusahaan.

Kinerja perusahaan $_{t}=\mathbf{a}+\mathbf{b}_{1}$.Pertumbuhan Perusahaan $_{t}+\mathbf{e}$

2) Menguji pengaruh pertumbuhan perusahaan dengan tingkat penggunaan utang.

DER $_{t}=\mathbf{a}+\mathbf{b}_{1}$, Pertumbuhan Perusahaan $+\mathbf{e}$

3) Menguji pengaruh tingkat penggunaan utang dengan kinerja perusahaan.

Kinerja Perusahaan $_{t}=\mathbf{a}+\mathbf{b}_{\mathbf{2}} \cdot \mathbf{D E R}_{\mathrm{t}}+\mathbf{e}$

4) Memasukkan tingkat penggunaan utang sebagai variabel kontrol dalam persamaan 1

Kinerja Perusahaan $_{t}=a+b_{1}$,.Pertumbuhan Perusahaan $_{t}+b_{2}$, DER $_{t}+e$

Efek mediasi bisa terpenuhi ketika persamaan 1, 2, dan 3 signifikan. Kemudian syarat selanjutnya adalah $b_{1}$, pada persamaan 4 bernilai 0 .

\section{HASIL PENELITIAN DAN PEMBAHASAN}

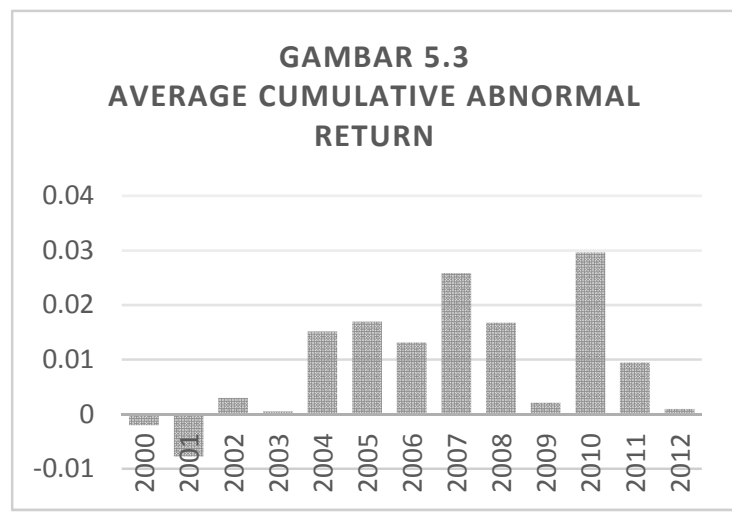

\section{Gambar 2 \\ Nilai ACAR}

Gambar tersebut menampilkan nilai Average Cumulative Abnormal Return (ACAR) yang digunakan sebagai proksi untuk menghitung kinerja perusahaan pasca pendanaan dengan utang pada perusahaan-perusahaan di masingmasing tahun. Berdasarkan Gambar 2, kinerja perusahaan sepanjang periode pengamatan baik karena kinerjanya melebihi kinerja pasar pada saat itu, kecuali pada tahun 2000 dan 2001 yang memiliki kinerja negatif (memburuk).

Setelah mendapatkan data secara deskriptif mengenai perilaku pendanaan utang perusahaan di Indonesia. Maka tahap selanjutnya adalah menguji secara statistik perilaku pendanaan tersebut terhadap kinerja perusahaan pada tahun setelahnya. Apabila kinerja pada tahun selanjutnya memburuk diakibatkan penggunaan utang perusahaan, maka perilaku reaktif pengambil keputusan di perusahaan terkait terbukti benar adanya. Prosedur pengujian dilakukan mengacu artikel dari Baron, dan Kenny (1986). Adapun tahapan pengujiannya adalah sebagai berikut:

1) Pengaruh pertumbuhan penjualan terhadap kinerja perusahaan

Pengujian ini sekaligus menguji hipotesis 1 dari penelitian ini yang menyatakan bahwa perusahaan dengan tingkat pertumbuhan tinggi akan memiliki kinerja memburuk dimasa yang akan datang, atau dengan kata lain bahwa pertumbuhan perusahaan berhubungan negatif dengan kinerja perusahaan. Tabel 1 menampilkan hasil pengujian statistiknya.

Tabel 1

Pengaruh Pertumbuhan Penjualan Terhadap Kinerja Perusahaan

\begin{tabular}{|c|c|}
\hline & Kinerja Perusahaan \\
\hline Pertumbuhan Penjualan & $-0,00007^{*}$ \\
& $(-1,48)$ \\
\hline
\end{tabular}

*signifikan di level 15\%

Berdasarkan Tabel 1, pertumbuhan perusahaan berpengaruh negatif terhadap kinerja perusahaan di 3 (tahun) yang akan datang. Hal ini ditunjukkan dengan nilai 
koefisien variable pertumbuhan penjualan sebesar -0,00007. Hal ini bermakna bahwa setiap kenaikan 1\% pertumbuhan perusahaan akan menurunkan kinerja perusahaan sebesar 0,007\%. Jadi untuk hipotesis 1 dalam penelitian ini terdukung, siginifikan pada level $15 \%$.

2) Pertumbuhan penjualan berpengaruh positif terhadap kebijakan penggunaan utang perusahaan

Langkah yang kedua ini sekaligus menguji hipotesis 2 penelitian ini serta menjawab rumusan masalah apakah perusahaan yang memiliki pertumbuhan penjualan tinggi akan cenderung menggunakan utang dalam kebijakan pendanaannya. Tabel VIII menampilkan hasil pengujian statistiknya.

\section{Tabel 2}

Pertumbuhan Penjualan dan Kebijakan Penggunaan Hutang Perusahaan

\begin{tabular}{|l|l|}
\hline & Debt to Equity Ratio (DER) \\
\hline $\begin{array}{l}\text { Pertumbuhan } \\
\text { Penjualan }\end{array}$ & $\begin{array}{l}0,037^{* *} \\
(1,63)\end{array}$ \\
\hline
\end{tabular}

**signifikan pada level $10 \%$

Berdasarkan Tabel 2, perusahaan dengan tingkat pertumbuhan yang tinggi akan cenderung meningkatkan penggunaan utang dalam keputusan pembiayaannya. Berdasarkan hasil uji statistik, 1\% peningkatan penjualan akan direspon dengan peningkatan $3,7 \%$ penggunaan utang. Hasil pengujian ini signifikan pada level $10 \%$ dan mendukung hipotesis yang kedua.

3) Pengaruh penggunaan utang terhadap kinerja perusahaan

Langkah berikut adalah langkah ketiga dari prosedur yang dikemukakan oleh Baron, dan Kenny (1986). Pengujian ini akan melihat efek dari penggunaan utang terhadap kinerja perusahaan. Tabel IX menampilkan hasil pengujian statistiknya.
Tabel 3

Pengaruh Penggunaan Hutang Terhadap Kinerja Perusahaan

\begin{tabular}{|l|c|}
\hline & Kinerja Perusahaan \\
\hline Debt to Equity & $0,0009^{*}$ \\
Ratio (DER) & $(1,53)$ \\
\hline
\end{tabular}

*signifikan pada level 15\%

Berdasarkan Tabel 3, penggunaan utang sebagai model kebijakan pembiayaan berpengaruh positif terhadap kinerja perusahaan. Atau dengan kata lain, 1\% kenaikan utang yang digunakan akan meningkatkan kinerja perusahaan sebesar 0,09\%. Hal ini tidak seperti yang diduga dalam penelitian ini. Dalam penelitian ini diduga bahwa kebijakan penggunaan utang berpengaruh negatif terhadap kinerja perusahaan. Karena penggunaan utang dipandang sebagai sebuah risiko yang dapat menurunkan kinerja perusahaan. Maka dari itu, hipotesis 3 yang menyatakan bahwa manajer berperilaku reaktif dalam kebijakan pendanaan tidak didukung dalam penelitian ini.

4) Pengujian pengaruh kebijakan utang, dan pertumbuhan penjualan terhadap kinerja perusahaan.

Langkah keempat ini adalah langkah terakhir dari prosedur Baron, dan Kenny (1986) untuk mengetahui efek mediasi dari kebijakan penggunaan utang. Dikatakan memediasi ketika nilai koefisien variabel independen pada pengujian poin (a) menjadi tidak signifikan ketika variabel mediasi (DER) dimasukkan dalam model. Pengujian ini sebenarnya akan digunakan sebagai penguji perilaku reaktif manajer dalam pengambilan keputusan kebijakan keuangan, dengan dugaan awal pertumbuhan penjualan berpengaruh negatif terhadap kinerja, kemudian pertumbuhan penjualan berpengaruh positif terhadap kebijakan penggunaan utang dan kebijakan 
penggunaan utang berpengaruh negatif terhadap kinerja. Dikatakan reaktif adalah ketika peningkatan penggunaan utang diambil oleh manajer ketika perusahaan sedang mengalami pertumbuhan penjualan yang kemudian dampaknya terjadi penurunan kinerja perusahaan. Akan tetapi, pengujian langkah ketiga justru menyatakan sebaliknya bahwa peningkatan penggunaan utang berpengaruh positif terhadap kinerja.

\section{Tabel 4}

Pengaruh Kebijakan Hutang, dan Pertumbuhan Penjualan Terhadap Kinerja Perusahaan

\begin{tabular}{|l|l|}
\hline & Kinerja Perusahaan (DV) \\
\hline $\begin{array}{l}\text { Pertumbuhan } \\
\text { Penjualan (IV) }\end{array}$ & $-0,00008^{* *}$ \\
& $(1,65)$ \\
Debt to Equity Ratio & $0,0002 * *$ \\
(MV) & $(-1,70)$ \\
\hline
\end{tabular}

**signifikan pada level $10 \%$

Berdasarkan Tabel 4, yang digunakan sebagai pengujian variabel mediasi tidak didukung. Dikatakan memediasi adalah ketika variabel mediasi (MV) dimasukkan dalam model maka variabel independen (IV) menjadi tidak signifikan. Dari hasil pengujian bahkan nilai koefisien IV tidak melemah tapi justru menjadi semakin kuat. Hal ini berimplikasi bahwa kebijakan utang tidak memediasi hubungan atara pertumbuhan penjualan dengan kinerja perusahaan.

\section{KESIMPULAN DAN SARAN}

Berdasarkan hasil penelitian ini, perusahaan yang berada pada fase pertumbuhan akan cenderung memiliki kinerja yang buruk dimasa yang akan datang. Hal ini dibuktikan dengan hasil uji statistik yang menyatakan bahwa pertumbuhan penjualan berpengaruh negatif terhadap kinerja perusahaan. Hasil penelitian ini setidaknya mengamini beberapa fenomena dalam dunia bisnis, bahwa beberapa perusahaan justru bangkrut ketika berada pada masa pertumbuhan. Hal ini mengingatkan kembali apa yang pernah Jim Collins katakana bahwa "good is the enemy of great", atau dengan kata lain bahwa kondisi yang dianggap bagus merupakan musuh utama dari kejayaan. Penelitian ini sebenarnya ingin mengurai fenomena tersebut dengan mengambil entry point penggunaan utang yang digunakan oleh perusahaan. Penggunaan utang dipandang sebagai sebuah kebijakan yang berisiko yang diambil secara reaktif oleh manajer sehingga berdampak buruk pada kinerja perusahaan. Akan tetapi hal itu tidak terbukti dalam penelitian ini. Yang terjadi justru sebaliknya bahwa kebijakan utang justru berdampak bagus bagi perusahaan, ini ditunjukkan dengan pengujian statistik pengaruh antara kebijakan penggunaan utang dengan kinerja perusahaan. Kebijakan penggunaan utang ketika perusahaan sedang tumbuh merupakan keputusan rasional seorang manajer yang mesti diambil, mengacu pada hasil penelitian ini. Jadi paradox tentang perusahaan yang sedang tumbuh dan memburuk dalam kinerja pada masa yang akan datang dalam penelitian ini belum teruraikan secara jelas. Akan tetapi yang pasti bahwa perusahaan yang sedang tumbuh rawan terjebak pada kebangkrutan terbukti dalam penelitian ini.

\section{DAFTAR PUSTAKA}

Anderson, C, Ronald. Mansi, A, Sattar. dan Reeb, M, David. (2003). Founding family ownership and the agency cost of debt. Journal of Financial Economics, 68, 263-285

Baron, R.M., dan Kenny, D.A.(1986). The Moderator-Mediator Variable Distinction in Social Psycological Research: Conceptual, Strategies, and Statistical Considerations. Journal of 
Personality and Social Psycology, 51, 1173-1182

Billet, T, Matthew. King, Tao-Hsien Dolly. dan Mauer, David. (2007). Growth Opportunities and the Choice of Leverage, Debt Maturity, and Covenants. The Journal of Finance, Vol. 62, No. 2, pp. $697-730$

Campello, Murillo. (2006). Debt financing: Does it boost or hurt firm performance in product markets?. Journal of Financial Economics, 82, 135-172

Gombola, Michael. dan Marciukaitye, Dalia. (2007). Managerial Overoptimism and the Choice between Debt and Equity Financing. The Journal of Behavioral Finance, Vol.8, No. 4, 225-235

Heaton, J.B. (2002). Managerial Optimism and Corporate Finance. Financial Management, Vol. 31, No. 2 (Summer, 2002), pp. 33-45.

Jensen, C, Michael. dan Meckling, H, William. (1976). Theory of the Firm: Managerial Behavior, Agency Costs and Ownership Structure. Journal of Financial Economics, V. 3, No. 4, pp. 305-360

Marciukaitye, Dalia. dan Szewczyk, H, Samuel. (2011). Financing Decisions and Discretionary Accruals: Managerial Manipulation or Managerial Overoptimism. Review of Behavioral Finance, 3, 91-114
Ramezani, A, Cyrus. Soenan, Luc. dan Jung, Alan. (2002). Growth, Corporate Profitability,and Value Creation. Financial Analyst Journal, November/ December 2002

Serrasqueiro, Ze'lia Silva. Armada, Manuel, Rocha. dan Nunes, Paulo, Macas. (2011). Pecking Order Theory versus Trade-Off Theory: are Service SMEs' capital structure decisions different? Service Business, 5, 381-409

Syam-Sunder, Lakhsmi. dan Myers, C, Stewart. (1999). Testing static trade of against pecking order models of capital structure. Journal of Financial Economics, 219244

Van Der Steen, Eric. (2004). Rational Overoptimism (and Other Bias). The American Economic Review, 94, 4, pg. 1141

Weinstein, D, Neil. (1980). Unrealistic Optimism about Future Life Events. Journal of Personality and Social Psychology, Vol. 39, No. 5, 806-820

Wu, Xeiping. dan Yeung, Kin Au, Chau. (2012). Firm Growth and Capital Structure Persistence. Journal of Business \& Banking, 36, 3427-3443

Yi, Jong-Hwan. (2001). Pre-offering earnings and the long-run performance of IPOs. International Review of Financial Analysis, 53 - 67. 